\title{
Effects of Inhibitors on the Catalysis and Immobilization of Cephalosporin C Acylase
}

\author{
H. Luo, ${ }^{a,{ }^{*}}$ K. Han, ${ }^{\mathrm{b}}$ Y. Chang, ${ }^{\mathrm{b}}$ Y. Wang, ${ }^{\mathrm{a}}$ S. Tong, \\ Z. Nie, ${ }^{a}$ X. Wang, ${ }^{a}$ Y. Wei, ${ }^{b}$ H. Yu, ${ }^{\mathrm{c}}$ and Z. Shen ${ }^{\mathrm{c}}$ \\ ${ }^{a}$ Department of Biological Science and Engineering, University \\ of Science and Technology Beijing, Beijing 100083, P. R. China \\ ${ }^{b}$ Department of Environmental Engineering, University of Science \\ and Technology Beijing, Beijing 100083, P. R. China \\ 'Department of Chemical Engineering, Tsinghua University, \\ Beijing 100084, P. R. China
}

doi: 10.15255/CABEQ.2016.1038

Original scientific paper

Received: November 17, 2016

Accepted: February 11, 2018

Numerous compounds, including weak bases (e.g., glucosamine, ethylenediamine, and pyridine) and weak acids (e.g., bicarbonate, acetate, propionate, and butyrate), were found to inhibit the catalysis of cephalosporin $\mathrm{C}$ acylase (CCA), which is a recombinant enzyme expressed in E. coli. Additionally, the protective effect of the inhibitors on free and immobilized CCA against heat treatment was investigated. The inhibitors were added to increase recovery of the activity of the enzyme immobilized by covalent attachment to an epoxy support. The activities of immobilized CCA obtained in the presence of acetate or bicarbonate were $99.2 \pm 2.5 \mathrm{U} \mathrm{g}^{-1}$ and $94.1 \pm 3.0 \mathrm{U} \mathrm{g}^{-1}$, respectively, which were $31.7 \%$ and $25 \%$ higher, respectively, than that of the control. In addition, the immobilized CCA exhibited improved thermostability. The half-life of immobilized CCA obtained in the presence of acetate or bicarbonate increased by $190 \%$ and $120 \%$, respectively, compared to that of immobilized CCA obtained in the absence of an inhibitor.

Keywords:

cephalosporin $\mathrm{C}$ acylase, inhibitor, immobilization, thermostability

\section{Introduction}

Cephalosporin C acylase (CCA) is an important enzyme that can directly catalyze the hydrolysis of cephalosporin $\mathrm{C}$ (CPC) to 7-aminocephalosporanic acid (7-ACA), which is the key intermediate for many semi-synthetic cephalosporins. The use of CCA in the bioprocessing of 7-ACA production is of great industrial interest as an environmentally friendly and economical alternative to chemical processes $^{1-2}$. Because of CCA's great industrial potential in the production of 7-ACA, the CCAs from Pseudomonas sp. (e.g., Pseudomonas sp. strains N176, SE83 and 130), which consist of two heterologous subunits, have attracted increased attention in the field of gene modification and for their catalytic properties $^{1-5}$.

For decades, enzymes have been used as highly efficient biocatalysts in the pharmaceutical and chemical industries ${ }^{6-7}$. In some cases, an enzyme decays at a higher rate under working conditions. This effect has been reported in the promotion of quaternary structure dissociation ${ }^{8}$, alteration of the oxidation stage in the active site $^{9}$, and catalytic

"Correspondence: e-mail: luohui@ustb.edu.cn; Tel.: + 86-10-82377396 auto-inactivation due to transient reactive intermediates ${ }^{10}$. Furthermore, inhibitors should be taken into consideration because many enzymes are reported to be sensitive to certain inhibitory compounds, and the binding of an inhibitor can stop the substrate from accessing the enzyme's active site or hinder the enzyme from catalyzing its reaction. Reversible inhibitors bind to enzymes with non-covalent interactions such as hydrogen bonds, hydrophobic interactions and ionic bonds, and the inhibitors can be easily removed by dilution or dialysis. There are three types of reversible inhibition: competitive inhibition, non-competitive inhibition, and uncompetitive inhibition. Competitive inhibition is a very common form in which inhibitors compete with the substrate for an enzyme's active sites, which lowers the enzyme's likelihood of binding the substrate and slows the observed reaction velocity ${ }^{11}$.

Inhibitors, including substrates and products, can sometimes act as protective agents for enzymes against inactivation ${ }^{12-13}$. Moreover, a technology named imprinting-immobilization has been developed to prevent the loss of enzyme activity in the enzyme immobilization processes. The presence of substrates or inhibitors may favor the enzyme's stability and ability to maintain the quaternary struc- 
ture due to the tightening of the enzyme active center $^{14}$. Considerable information has been gathered in recent years concerning mechanisms and modeling of the inhibition mechanism of enzymes ${ }^{11}$. It has been suggested that anything favoring a rigid enzyme molecular configuration could improve an enzyme's stability ${ }^{15-16}$. Thus, some inhibitors that interact with the enzyme structure during immobilization might exert a protective effect against the inactivation process.

Enzyme inhibitors have been investigated with a series of enzymes, such as trypsin, penicillin acylase, and lipase ${ }^{12-13,17}$. To the best of our knowledge, there are no reports on the effect of inhibitors on the catalysis and stability of CCA, let alone the application of inhibitors in the process of immobilization. Most inhibitors of enzymes include the substrate, the product and its analogues, and metal ions. Weak acids and bases sharing no common structure with the substrates or products are not well-known inhibitors $^{12-13,18}$

In this study, a group of compounds containing weak acids and bases were tested as inhibitors of CCA. The influences of these chemicals on the catalysis and thermostability of the enzyme were investigated, and the application of these chemicals as protective agents in immobilization were also studied.

\section{Materials and methods}

\section{Materials}

CPC and 7-ACA were kindly supplied by the North China Pharmaceutical Co., Ltd. (Shijiazhuang, China). Amicon Ultra centrifugal filter devices were purchased from Millipore (Boston, USA). Epoxy resin carrier LX-1000EP was kindly supplied by Sunresin New Materials Co., Ltd. (Xi'an, China). All other chemicals were of analytical grade.

\section{Preparation of CCA}

A gene encoding CCA from Pseudomonas sp. SE83 was optimized and inserted into a prokaryotic expression plasmid pET-28 ${ }^{19}$. The constructed recombinant E. coli BL21(DE3)/pET-CPCAcy was cultivated with a lactose auto-induction medium and CCA was subsequently purified by immobilized metal affinity chromatography, as described in our previous work ${ }^{4}$. Purified CCA was stored at $4{ }^{\circ} \mathrm{C}$ for further enzymatic characterization and immobilization.

\section{Assay of CCA activity}

The enzyme activity of CCA against CPC was measured according to a previously described meth- od with minor modifications ${ }^{20-21}$. A substrate solution was made by dissolving CPC in sodium phosphate buffer $\left(0.1 \mathrm{~mol} \mathrm{~L}^{-1} ; \mathrm{pH} 8.0\right)$ at a concentration of $20 \mathrm{mg} \mathrm{mL}^{-1}$, and the $\mathrm{pH}$ value was adjusted to 8.5 with $1 \mathrm{~mol} \mathrm{~L}^{-1} \mathrm{NaOH}$. The $\mathrm{CPC}$ solution was mixed with the enzyme solution, and then the reaction mixture was incubated at $37^{\circ} \mathrm{C}$ for $5 \mathrm{~min}$. The reaction was terminated with a mixture of $20 \%$ (v/v) acetic acid and $0.05 \mathrm{~mol} \mathrm{~L}^{-1} \mathrm{NaOH}$ in a $2: 1$ ratio. Then, $0.5 \%(\mathrm{w} / \mathrm{v}) \mathrm{p}$-dimethylaminobenzaldehyde dissolved in methanol was added to the mixture, and the reaction mixture was then incubated at room temperature for $10 \mathrm{~min}$. The absorbance was measured at a wavelength of $415 \mathrm{~nm}$. One unit of CCA activity was defined as the amount of enzyme capable of producing $1 \mu \mathrm{mol}$ of 7-ACA per minute at $37{ }^{\circ} \mathrm{C}$ and $\mathrm{pH} 8.5$.

The specific activity of the immobilized enzyme was determined by using the same method, and it was then defined as $\mu$ moles of 7-ACA produced per minute and per gram of wet resin under the previously described conditions.

\section{Conversion of CPC using immobilized CCA in different buffers}

The conversion reaction was performed in a jacketed glass reactor ${ }^{4}$. After the immobilized enzyme was added, the substrate of $30 \mathrm{mg} \mathrm{mL}^{-1} \mathrm{CPC}$ was dissolved in different solutions, including 50 mmol L ${ }^{-1}$ sodium acetate, $50 \mathrm{mmol} \mathrm{L}-1$ sodium bicarbonate, $50 \mathrm{mmol} \mathrm{L}^{-1}$ sodium phosphate buffer, and $50 \mathrm{mmol} \mathrm{L}^{-1}$ Tris-HCl buffer, and added into the reactor. The reaction mixture was kept at $20{ }^{\circ} \mathrm{C}$ and $100 \mathrm{rpm}$. The $\mathrm{pH}$ value of the reaction was maintained at 8.5 by adding $2 \mathrm{~mol} \mathrm{~L}^{-1}$ ammonium hydroxide.

The samples were periodically withdrawn and analyzed through HPLC with a Phenomenex Luna $\mathrm{C}-18$ column $(4.6 \times 150 \mathrm{~mm})$. The mobile phase consisted of acetonitrile, methanol, and 1\% (v/v) aqueous acetic acid at a ratio of $7.5: 15: 77.5$. The flow rate was $0.8 \mathrm{~mL} \mathrm{~min}^{-1}$ and the UV detector was set at $254 \mathrm{~nm}$. The retention times for 7-ACA and CPC were 2.3 and $3 \mathrm{~min}$, respectively.

\section{Influence of inhibitors on the activity of free CCA}

The influence of inhibitors, such as sodium salts of weak acids, including acetate, bicarbonate, lactate, formate, acetate, propionate, and butyrate, and some weak bases, including ethanolamine, glucosamine, and pyridine, on the enzymatic activity was tested at $37^{\circ} \mathrm{C}$. The sodium acetate and sodium bicarbonate were tested at the following concentrations: $0,20,50,100,200,500 \mathrm{mmol} \mathrm{L}^{-1}$, and ethanolamine, glucosamine, pyridine, and all of the other 
weak acids were measured at $50 \mathrm{mmol} \mathrm{L}^{-1}$. All of the inhibitors were prepared by dissolving them in $0.1 \mathrm{~mol} \mathrm{~L}^{-1}$ sodium phosphate buffer and adjusting the $\mathrm{pH}$ value to 8.5 .

\section{Kinetic parameters of CCA with inhibitors}

The kinetic parameters were determined by the initial rates. Firstly, the initial reaction rate of the free enzyme was measured at $37{ }^{\circ} \mathrm{C}$ in sodium phosphate buffer $\left(0.1 \mathrm{~mol} \mathrm{~L}^{-1} ; \mathrm{pH} 8.0\right)$ with the CPC solution prepared at different concentrations $\left(10-50 \mathrm{mmol} \mathrm{L}^{-1}\right)$ and the $\mathrm{pH}$ value adjusted to 8.5. Next, a certain amount of inhibitor was added to the substrate at different concentrations to evaluate the inhibitory effects. Lastly, the Lineweaver-Burk method was applied to determine the inhibition type and the Michaelis constant. The involved inhibitors were studied under the same conditions, including sodium acetate, sodium bicarbonate, ethanolamine and glucosamine at concentrations of $50 \mathrm{mmol} \mathrm{L}^{-1}$ and $100 \mathrm{mmol} \mathrm{L}^{-1}$. To investigate the effect of the substrate on CCA, the concentrations of cephalosporin $\mathrm{C}$ ranging from 10 to $100 \mathrm{mmol} \mathrm{L}^{-1}$ were prepared for CCA activity determination. The product 7-ACA ( 2 and $3 \mathrm{mg} \mathrm{mL}^{-1}$ ) was also added into the CPC solution to test its inhibitory effect on CCA.

\section{Influence of inhibitors on the thermostability of immobilized CCA}

The immobilized CCA was incubated at $50{ }^{\circ} \mathrm{C}$ in sodium phosphate buffer $\left(20 \mathrm{mmol} \mathrm{L}^{-1}, \mathrm{pH} 8.0\right)$ with different inhibitors, including sodium acetate and sodium bicarbonate. All of the inhibitors were dissolved in sodium phosphate buffer to obtain a final concentration of $50 \mathrm{mmol} \mathrm{L}^{-1}$, and then the $\mathrm{pH}$ value of the system was adjusted to 8.0. After incubation for 20, 40, 60 and $120 \mathrm{~min}$, the immobilized enzyme was sampled and repeatedly washed with sodium phosphate buffer to thoroughly remove the inhibitors. The samples were then used to determine the residual activity.

\section{Immobilization of CCA with inhibitors}

A type of epoxy support, LX-1000EP, was suspended in sodium phosphate buffer $\left(0.9 \mathrm{~mol} \mathrm{~L}^{-1} ; \mathrm{pH}\right.$ 8.0), and then an appropriate volume (enzyme loading amount was 400 units per gram support) of enzyme solution was mixed with $50 \mathrm{mmol} \mathrm{L}^{-1}$ sodium acetate and $50 \mathrm{mmol} \mathrm{L}^{-1}$ sodium bicarbonate. At the same time, a blank controlled trial was conducted in the absence of inhibitor. The suspension was maintained under mild stirring for $24 \mathrm{~h}$ at $25^{\circ} \mathrm{C}$. Afterwards, the immobilized CCA was recovered by filtration, thoroughly washed with sodium phosphate buffer to remove the inhibitors, and stored at $4{ }^{\circ} \mathrm{C}$ until further use.

\section{Thermostability assay of immobilized CCA}

The thermostability of each immobilized CCA preparation was determined by measuring the residual activity after incubation in sodium phosphate buffer $\left(20 \mathrm{mmol} \mathrm{L}^{-1} ; \mathrm{pH} 8.0\right)$ at $50{ }^{\circ} \mathrm{C}$ for $1 \mathrm{~h}$. The samples were taken at intervals to determine the residual activity. The initial value of enzymatic activity in each set was arbitrarily assigned a value of $100 \%$.

\section{Results and discussion}

\section{Conversion of CPC using immobilized CCA in different buffers}

Enzyme immobilization is a key technology in biocatalytic process development, and the carrier-immobilized enzymes are widely used in largescale bio-manufacturing ${ }^{6-7}$. Usually, the $\mathrm{pH}$ value plays an important role in the catalysis of immobilized enzymes, and each enzyme has an optimum $\mathrm{pH}$ range. According to our previous research, the optimal $\mathrm{pH}$ value for the free CCA was 8.5 , while for immobilized CCA it was 8.5 to $9.5^{4}$. The immobilized enzyme requires more alkaline conditions for maximum enzyme activity compared to the free enzyme, which is partially because of the $\mathrm{pH}$ gradient in the carrier led by the acidic products. Considering immobilized hydrolases ${ }^{22-24}$, the intraparticle $\mathrm{pH}$ gradients could affect the catalytic performances not only in the apparent kinetic properties of the en$\mathrm{zyme}^{25-26}$ but also because of the influence of $\mathrm{pH}$ on protein stability $5,7,27$.

To improve the efficiency of the conversion of CPC with the immobilized enzyme, the catalysis of CCA was performed in buffer systems primarily to reduce the $\mathrm{pH}$ difference between the intraparticle environment and the bulk solution. Unexpectedly, the result showed that conversion in pure water was the fastest (Fig. 1). The sodium phosphate buffer and Tris- $\mathrm{HCl}$ buffer had very little impact on the reaction velocity, but interestingly, the sodium acetate and sodium bicarbonate buffer significantly influenced the results. This suggests that there is a reversible inhibition on the enzyme by weak acids that may slow down the reaction velocity.

\section{Influence of inhibitors on the activity of free CCA}

The results of the CPC catalysis in buffer revealed that the enzyme activity was clearly affected by sodium acetate and sodium bicarbonate, and the higher the concentration, the stronger the inhibition effect. Sodium acetate exerted stronger inhibition compared with sodium bicarbonate at the same concentration (Fig. 2a). In addition, the enzyme activity 


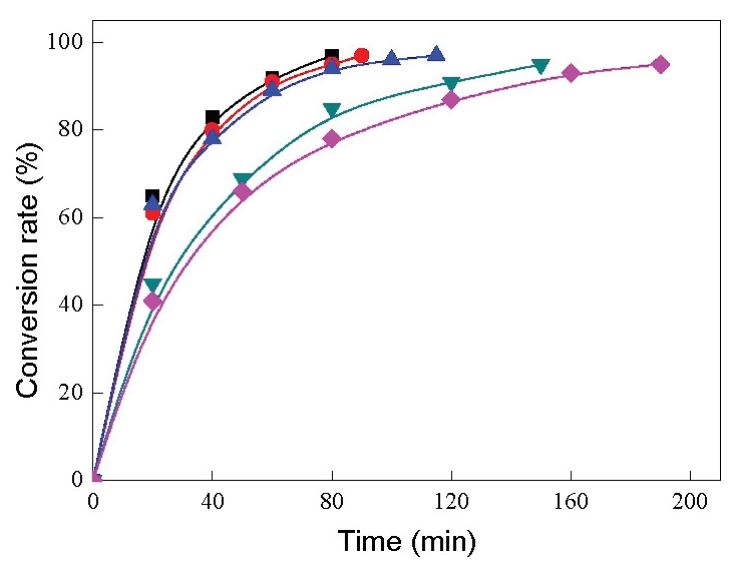

Fig. 1 - Catalysis of CPC with the immobilized CCA in different buffers. Water (square); phosphate (circle); Tris- $\mathrm{HCl}$ (up-triangle); bicarbonate (down-triangle); acetate (diamond).

was also inhibited by many weak acids, including lactic acid, formic acid, acetic acid, propionic acid, and butyric acid (Fig. 2b). Interestingly, the butyric acid $(\mathrm{pKa}=4.81)$ had a more significant effect on the inhibition of the enzyme activity than lactic acid $(\mathrm{pKa}=3.86)$, formic acid $(\mathrm{pKa}=3.75)$, acetic acid $(\mathrm{pKa}=4.75)$, and propionic acid $(\mathrm{pK}=4.87)$. This suggests that the inhibitory effect correlates with both the $\mathrm{pKa}$ values and the hydrophobic properties and/or chain length (steric hindrance) of the inhibitors.

Interestingly, CCA was also inhibited by basic compounds, such as pyridine, glucosamine and ethanolamine (Fig. 2c). When compared with the other basic compounds, the inhibition of pyridine $(\mathrm{pKa}=$ 5.19) was slightly weaker at a low concentration. The degree of inhibition with glucosamine $(\mathrm{pKa}=$ 7.78) was very similar to that of ethanolamine ( $\mathrm{pKa}$ $=9.45$ ), although the basicity and structure of the two chemicals are different.

It was reported that substrates and products sometimes inhibit the enzymes activity ${ }^{13,14}$. The substrate of CPC sodium salt was found to cause no inhibition on CCA at concentrations up to 100 mmol L ${ }^{-1}$, which is a concentration much higher than that used in the industry. The product 7-ACA showed obvious inhibitory effects on CCA even at low concentrations of $2 \mathrm{mg} \mathrm{mL}{ }^{-1}$, which suggests that the product inhibition on CCA should be seriously considered during the industrial production of 7-ACA ${ }^{28}$.

\section{Kinetic parameters of enzyme with inhibitors}

To evaluate the inhibitory effect of the inhibitors, experiments were conducted with inhibitors (50 or $100 \mathrm{mmol} \mathrm{L}^{-1}$ ) and substrates ranging from 10 to $50 \mathrm{mmol} \mathrm{L}^{-1}$. The inhibition of sodium acetate is greater than sodium bicarbonate (Fig. 3a), and

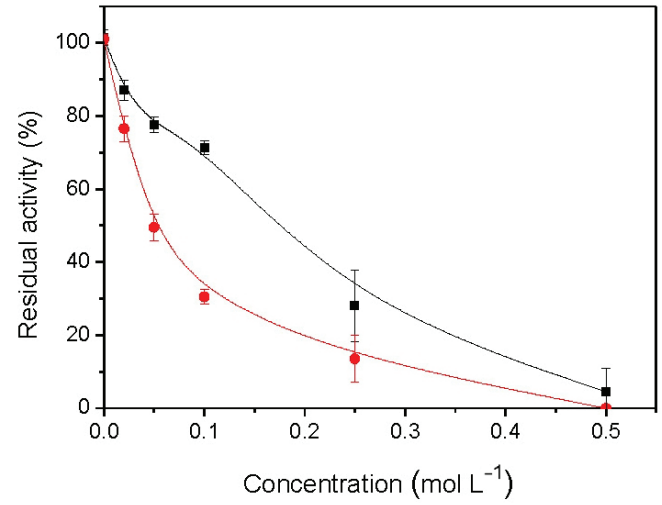

(a)

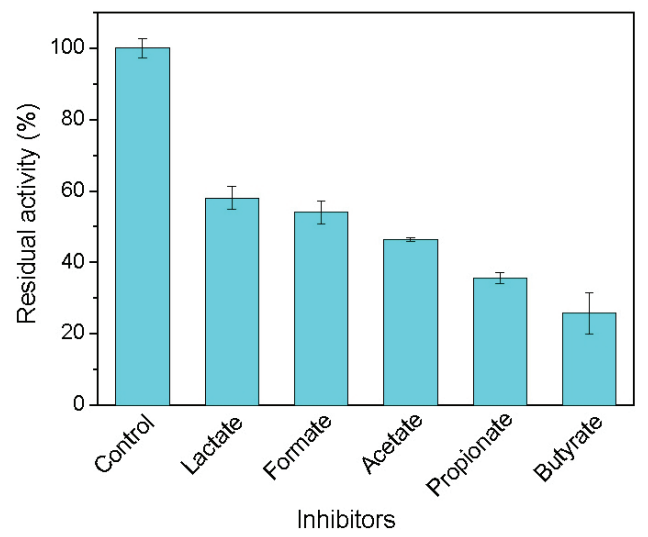

(b)

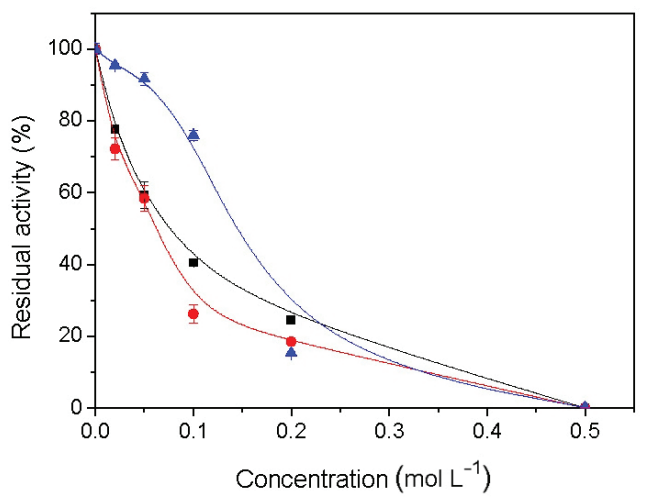

(c)

Fig. 2 - Enzyme activity in the presence of inhibitors. (a) Influence of sodium acetate (square) and sodium bicarbonate (circle) on the activity of free CCA; (b)Influence of $50 \mathrm{mmol} \mathrm{L^{-1 }}$ lactate, formate, acetate, propionate, and butyrate on enzyme activity; and (c) Influence of pyridine (triangle), glucosamine (square) and ethanolamine (circle) on the activity of free CCA.

glucosamine shows a stronger inhibitory effect on CCA than ethanolamine (Fig. 3b).

The higher concentrations of inhibitors had greater inhibitory effects on CCA. Based on the Lineweaver-Burk plots, the addition of inhibitors to the reaction medium led to the competitive inhibition of CCA catalysis (Fig. 3). This result suggests that inhibitors may behave similarly to the substrate, 


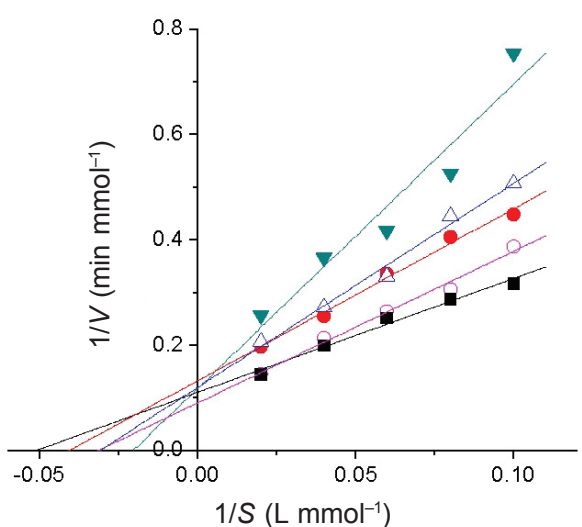

(a)

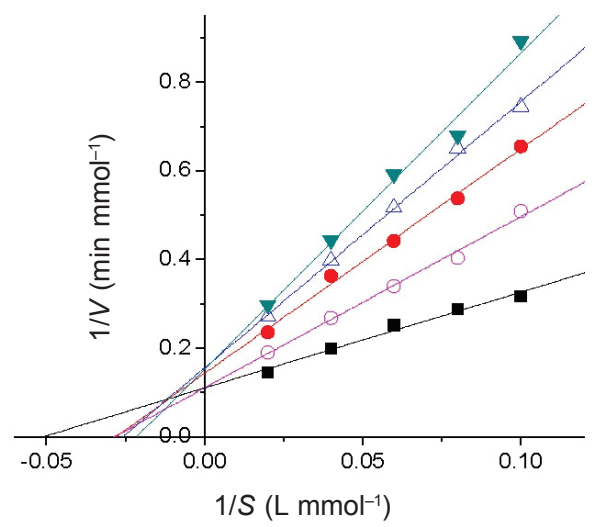

(b)

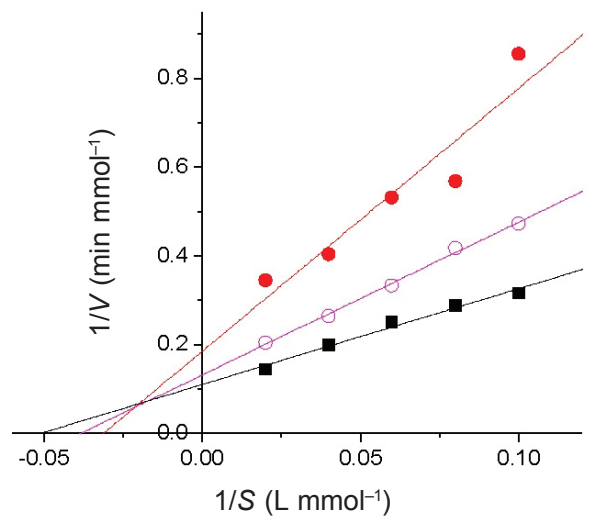

(c)

F ig. 3 - Kinetic studies of free CCA with inhibitors: (a) Effect of a weak-acid sodium salt with the addition of $50 \mathrm{mmol} \mathrm{L^{-1 }}$ acetate (open triangle), $100 \mathrm{mmol} \mathrm{L^{-1 }}$ acetate (solid triangle),

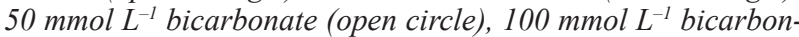
ate (solid circle) and no inhibitor (square); (b) Effect of a weak

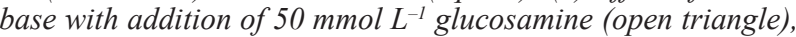
$100 \mathrm{mmol} \mathrm{L^{-1 }}$ glucosamine (solid triangle), $50 \mathrm{mmol} \mathrm{L^{-1 }}$ ethanolamine (open circle), $100 \mathrm{mmol} \mathrm{L^{-1 }}$ ethanolamine (solid circle) and no inhibitor (square); and (c) Effect of product

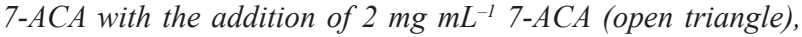
$3 \mathrm{mg} \mathrm{mL^{-1 }}$ 7-ACA (solid triangle) and no inhibitor (square)

i.e., binding the active site of the enzyme and blocking the access of the substrate to the active site or reducing the enzyme-substrate affinity. The $K_{\mathrm{mi}}$ values of CCA with different inhibitors (at a concentra-

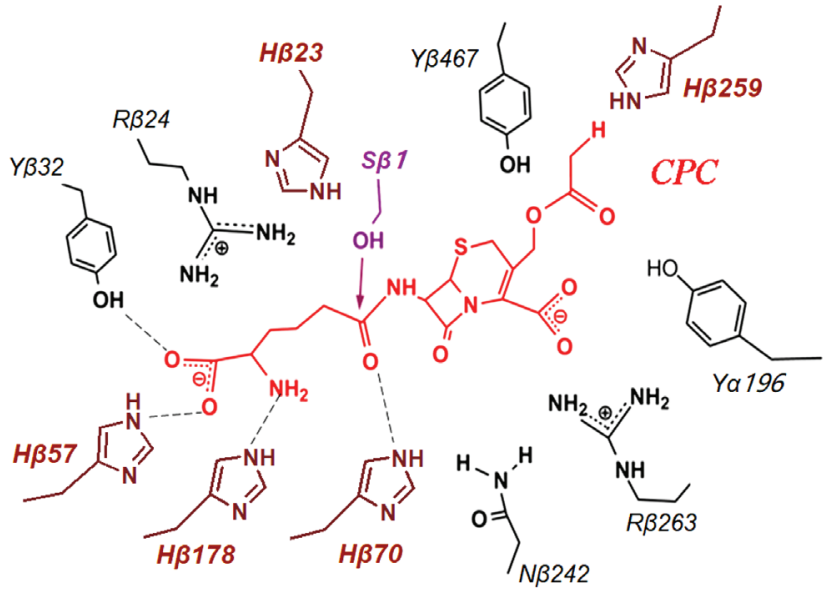

Fig. 4 - Schematic diagram of the hydrogen-bond network in the CCA-CPC complex within $4 A$ in the catalytic sites. The arrow indicates the position of the site of cephalosporin $C$ (red) hydrolysis with respect to the OH-group of $S \beta 1$ (purple). The histidine residues in the substrate-binding cavity are bolded (brown). The other residues close to the substrate in the catalytic sites are in black. The dashed lines represent hydrogen bonds. Distances are not represented to scale.

tion of $50 \mathrm{mmol} \mathrm{L}^{-1}$ ) were $32.63 \pm 3.4 \mathrm{mmol} \mathrm{L}^{-1}$ (acetate), $27.06 \pm 1.48 \mathrm{mmol} \quad \mathrm{L}^{-1} \quad$ (bicarbonate), $44.54 \pm 24.26 \mathrm{mmol} \mathrm{\textrm {L } ^ { - 1 }}$ (glucosamine), and $46.02 \pm 1.42 \mathrm{mmol} \mathrm{L}^{-1}$ (ethanolamine), whereas the $K$ value of the free CCA without the inhibitor was $19.58 \pm 2.16 \mathrm{mmol} \mathrm{L}^{-1}$.

\section{Mechanism of competitive inhibition}

The CCA was inhibited by weak acids and bases, which suggests the presence of an essential histidine residue at the substrate-binding region of the active sites ${ }^{29-31}$. The CCA in this work originated from Pseudomonas SE83 ${ }^{19}$ and shares a homology of approximately $93 \%$ with the CCA from Pseudomonas N176. The protein structure of SE83 CCA could be obtained through computational modeling with the recently determined X-ray crystal structure of N176 CCA (PDB accession code 4HST) as the template ${ }^{31-32}$. As shown in Fig. 4, there are few histidine residues situated at or near the active site of the enzyme ( $4 \AA$ within the substrate-binding domain) that are essential for activity.

The conjugate acid (protonated form) of the imidazole side chain in histidine has a $\mathrm{pKa}$ of approximately 6.0. It was speculated that the anions of weak acids or cations of the bases could interact with the imidazole group of the histidine residues at the active sites, which have a microenvironment with an acidic $\mathrm{pH}(\sim \mathrm{pH} 6-7)$ during the catalysis of $\mathrm{CPC}$ with the immobilized enzyme 5 .

In the industrial process of CPC separation, the CPC fermentation broth is absorbed onto macroporous resin and then eluted by either an acetate or bicarbonate aqueous solution ${ }^{33-35}$. The CPC solution prepared for 7-ACA production in industry usually 
contains a weak acid salt: either sodium acetate or bicarbonate. Therefore, sodium acetate and sodium bicarbonate were further investigated among the inhibitors mentioned above.

\section{Influence of inhibitors on the thermostability of immobilized CCA}

It was reported that most penicillin acylases are inhibited by their product, 6 -aminopenicillanic acid (6-APA), which is a noncompetitive inhibitor, and penicillin acylases can also be protected against thermal inactivation by $6-\mathrm{APA}^{13}$. To determine if the inhibitors could improve the thermal stability of $\mathrm{CCA}$, which is a heterogeneous dimeric protein like penicillin acylases, the immobilized CCA was incubated at $50{ }^{\circ} \mathrm{C}$ in the presence of sodium acetate and sodium bicarbonate. The results indicated that the immobilized enzyme, in the presence of inhibitors, had a higher thermostability than the control (Fig. 5). The half-life of the samples increased in the presence of sodium acetate and sodium bicarbonate by $160 \%$ and $360 \%$, respectively, compared to that of the enzyme in the absence of inhibitors. The conformation of the enzyme molecule can be changed by substantially decreasing its bioactivity and stability during heat treatment. However, in some cases, the inhibitors bound to the enzyme can maintain their conformation efficiently, which might be a sound explanation for the protective effect of inhibitors on immobilized CCA.

\section{Immobilization of CCA in the presence of inhibitors}

The epoxy-activated supports are ideal matrixes to perform a simple immobilization of proteins and have been used to immobilize various commer-

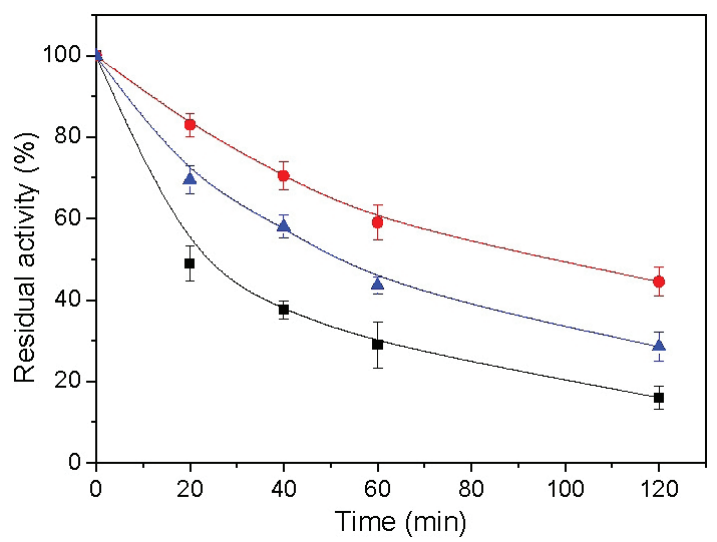

Fig. 5 - Thermostability of immobilized CCA in the presence of inhibitors. The immobilized CCA was incubated at $50{ }^{\circ} \mathrm{C}$ in sodium phosphate buffer $\left(20 \mathrm{mmol} \mathrm{L}^{-1}\right.$; $\mathrm{pH}$ 8.0) with $50 \mathrm{mmol} \mathrm{L}^{-1}$ sodium acetate or sodium bicarbonate. The enzyme activity was measured after the inhibitors were thoroughly washed out with phosphate buffer. No inhibitor (triangle), sodium bicarbonate (circle), and sodium acetate (square).
Table 1 -Immobilization of CCA in the presence of inhibitors

\begin{tabular}{l|c|c|c}
\hline \multicolumn{1}{c|}{ Inhibitor } & Control & $\begin{array}{c}\text { Sodium } \\
\text { acetate }\end{array}$ & $\begin{array}{c}\text { Sodium } \\
\text { bicarbonate }\end{array}$ \\
\hline Apparent activity $\left(\mathrm{U} \mathrm{g}^{-1}\right)$ & $75.3 \pm 3.8$ & $99.2 \pm 2.5$ & $94.1 \pm 3.0$ \\
Yield (\%) & $18.8 \pm 0.95$ & $24.8 \pm 0.62$ & $23.5 \pm 0.75$ \\
\hline
\end{tabular}

cial enzymes via multipoint covalent attachment ${ }^{16}$. It was reported that enzymes could be easily inactivated by a neighboring unbound activated group (aldehyde or epoxy) on the carrier in the process of immobilization $^{36}$. There is minimal literature on the stabilization of enzymes by additives during immobilization $^{37}$. Because competitive inhibitors can bind with the enzyme through its binding sites and form enzyme-inhibitor complexes, the enzyme can be protected from conformational changes caused by unspecific binding with the excess epoxy groups.

In this work, inhibitors were used in the process of immobilization. The product 7-ACA and weak bases were not chosen because they have amino-groups that could react with the epoxy groups on the carrier. Sodium acetate and sodium bicarbonate were then added to the immobilized system, and the apparent enzyme activities of the immobilized enzyme and the yields of activity were determined (Table 1).

In the presence of sodium acetate, the highest activity yield was approximately $25 \%$ and the highest immobilized enzyme activity was $99.2 \pm 2.5$ $\mathrm{U} \mathrm{g}^{-1}$ (Table 1). The immobilized enzyme with sodium acetate showed a $31.7 \%$ increase in activity and a $25 \%$ increase with sodium bicarbonate. Inhibitors offered protection to enzymes, especially in sodium acetate, probably due to its stronger inhibitory action. With the binding of inhibitors, the enzyme molecules are likely to gain extra rigidity against the distortion in the process of covalent binding. Another possible reason for the improvement of immobilization yield with inhibitors might be the reduced exposure of enzyme molecules to excess epoxy groups (i.e., the neighboring unbound activated groups) on the carrier.

\section{Thermostability of the inhibitor-protected immobilized CCA}

Enzymes are inherently labile, even after immobilization; therefore, their operational stability is of great importance for any bioprocess. Thermostability is a factor closely related to operational stability, and most research has focused on thermostability during enzyme reactions because it is a convenient test $\mathrm{t}^{38-40}$.

In the immobilization process of CCA, inhibitors of sodium acetate and sodium bicarbonate show 


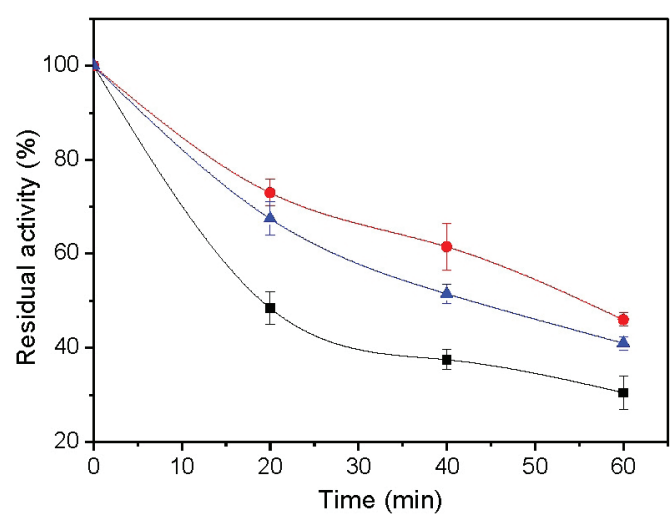

Fig. 6 - Thermostability of immobilized CCA obtained in the presence of inhibitors. The immobilized CCA preparations were incubated at $50{ }^{\circ} \mathrm{C}$ in sodium phosphate buffer $\left(20 \mathrm{mmol} \mathrm{L} \mathrm{L}^{-1}\right.$; pH 8.0). Enzyme activity was measured periodically, and the activity of the untreated enzyme was assigned as $100 \%$. No inhibitor (triangle), sodium bicarbonate (circle), and sodium acetate (square).

the potential to improve the activity of the immobilized enzyme, and the obtained catalysts were also found to have better thermostability than the control (Fig. 6). The half-life of the immobilized CCA obtained in the presence of sodium acetate increased by $190 \%$ compared to the control, and the samples obtained with sodium bicarbonate exhibited a 120 $\%$ increase in thermostability.

It was speculated that the conformational flexibility of the enzyme might be impaired in the immobilization process, and decreased conformational flexibility is often the reason why an immobilized enzyme shows higher stability than free enzyme ${ }^{41}$. It is commonly recognized that inhibitors have a stabilizing effect on the three dimensional conformation of enzymes ${ }^{12,42}$. Use of inhibitors as protective agents can help shield enzymatic properties during the immobilized process, and the rigid configuration can be retained after immobilization by multi-point covalent attachment to supports. This significant thermostability improvement could be ascribed to the increase in enzyme rigidity and the change of the microenvironment around the enzyme in the immobilization process. The better result obtained by sodium acetate is likely because the degree of inhibition by sodium acetate is stronger than that of sodium bicarbonate. As a consequence, sodium acetate tends to protect both the free and immobilized enzymes from inactivation more effectively.

\section{Conclusions}

Inhibitors are an important aspect of enzyme research. In this work, some untraditional inhibitors, including weak bases (e.g., glucosamine, ethylenediamine, and pyridine) and acids (e.g., bicar- bonate, formate, acetate, propionate, and butyrate) exhibited an inhibitory effect on the catalytic process with CCA. Although the existence of these compounds retards enzymatic catalysis, some of these inhibitors can act as protectives agents in the thermal treatment of immobilized enzyme and in the process of immobilization to improve the activity recovery and stability of the immobilized enzyme. The increased stability and activity recovery in the process of immobilization might be attributed to the increase in the enzyme rigidity via binding of inhibitors with CCA at the active sites. The increased molecular rigidity was retained even after enzyme immobilization in the presence of inhibitors and endowed the immobilized enzyme with higher thermostability than the control. Furthermore, the increase in thermostability and activity of the immobilized enzyme seems somewhat related to the extent of inhibition exerted by the inhibitors. Because of its good thermostability and activity, the immobilized CCA (with the aid of inhibitors) presents good potential in the process of 7-ACA production on a large scale. It is obvious that the immobilization technique using weak acids or bases described in this work will provide a broader spectrum of derivatives apart from traditional inhibitors, such as products or polyglycols in enzyme immobilization.

\section{ACKNOWLEDGMENTS}

This work was supported by the National Natural Science Foundation of China (21476025; 21276023) and the Beijing Natural Science Foundation (2143041). The authors would also like to thank the North China Pharmaceutical Co., Ltd. for the generous supply of CPC and 7-ACA, and Sunresin New Materials Co., Ltd. for generously providing LX-1000EP support.

\section{Abbreviations}

CCA - cephalosporin $\mathrm{C}$ acylase

E. coli - Escherichia coli

7-ACA - 7-aminocephalosporanic acid

CPC - cephalosporin C

$K_{\mathrm{m}} \quad-$ Michaelis constant, $\mathrm{mmol} \mathrm{\textrm {dm } ^ { - 3 }}$

\section{References}

1. Pollegioni, L., Rosini, E., Molla, G., Cephalosporin C acylase: dream and(/or) reality, Appl. Microbiol. Biotechnol. 97 (2013) 2341. doi: https://doi.org/10.1007/s00253-013-4741-0

2. Sonawane, V. C., Enzymatic modifications of cephalosporins by cephalosporin acylase and other enzymes, Crit. Rev. Biotechnol. 26 (2006) 95.

doi: https://doi.org/10.1080/07388550600718630 
3. He, H., Wei, Y., Luo, H., Li, X., Wang, X., Liang, C., Chang, $Y$., $Y u, H$., Shen, Z., Immobilization and stabilization of cephalosporin $\mathrm{C}$ acylase on aminated support by crosslinking with glutaraldehyde and further modifying with aminated macromolecules, Biotechnol. Prog. 31 (2015) 387 doi: https://doi.org/10.1002/btpr.2044

4. Zhu, X., Luo, H., Chang, Y., Su, H., Li, Q., Yu, H., Shen, Z., Characteristic of immobilized cephalosporin $\mathrm{C}$ acylase and its application in one-step enzymatic conversion of cephalosporin $\mathrm{C}$ to 7-aminocephalosporanic acid, World J. Microb. Biot. 27 (2011) 823. doi: https://doi.org/10.1007/s11274-010-0523-3

5. Boniello, C., Mayr, T., Klimant, I., Koenig, B., Riethorst, W., Nidetzky, B., Intraparticle concentration gradients for substrate and acidic product in immobilized cephalosporin $\mathrm{C}$ amidase and their dependencies on carrier characteristics and reaction parameters, Biotechnol. Bioeng. 106 (2010) 528. doi: https://doi.org/10.1002/bit.22694

6. Sheldon, R. A., Enzyme immobilization: The quest for optimum performance, Adv. Syn. Cat. 349 (2007) 1289 doi: https://doi.org/10.1002/adsc.200700082

7. Buchholz, K., Kasche, V., Bornscheuer, Uwe T., Biocatalysts and enzyme technology, John Wiley \& Sons, Weinheim, 2012, pp 2-32.

8. Bolivar, J. M., Rocha-Martín, J., Mateo, C., Guisan, J. M., Stabilization of a highly active but unstable alcohol dehydrogenase from yeast using immobilization and post-immobilization techniques, Process Biochem. 47 (2012) 679. doi: https://doi.org/10.1016/j.procbio.2012.01.012

9. Bourdillon, C., Thomas, V., Thomas, D., Electrochemical study of D-glucose oxidase autoinactivation, Enzyme Microb. Tech. 4 (1982) 175.

doi: https://doi.org/10.1016/0141-0229(82)90113-2

10. Bourdillon, $C$., Hervagault, C., Thomas, D., Increase in operational stability of immobilized glucose oxidase by the use of an artificial cosubstrate, Biotechnol. Bioeng. 27 (1985) 1619.

doi: https://doi.org/10.1002/bit.260271119

11. Cornish-Bowden, A., Principles of enzyme kinetics, Butterworth Publ., 2014, pp 52-70.

12. Blanco, R. M., Guisán, J., Protecting effect of competitive inhibitors during very intense insolubilized enzyme-activated support multipoint attachments: trypsin (amine)-agarose (aldehyde) system, Enzyme Microb. Tech. 10 (1988) 227. doi: https://doi.org/10.1016/0141-0229(88)90071-3

13. Ospina, S. S., Lopez-Munguia, A., Gonzalez, R. L., Quinte$r o, R$., Characterization and use of a penicillin acylase biocatalyst, J. Chem. Tech. Biotechnol. 53 (1992) 205. doi: https://doi.org/10.1002/jctb.280530217

14. Cao, L., Immobilised enzymes: science or art?, Current opinion in chemical biology 9 (2005) 217. doi: https://doi.org/10.1016/j.cbpa.2005.02.014

15. Bickerstaff, G. F., Applications of immobilised enzymes to fundamental studies on enzyme structure and function, Topics Enzyme Ferm. Biotechnol. 9 (1984) 162.

16. Mateo, C., Palomo, J. M., Fernandez-Lorente, G., Guisan, $J$. M., Fernandez-Lafuente, R., Improvement of enzyme activity, stability and selectivity via immobilization techniques, Enzyme Microb. Tech. 40 (2007) 1451. doi: https://doi.org/10.1016/j.enzmictec.2007.01.018

17. Laskowski Jr, M., Kato, I., Protein inhibitors of proteinases, Annu. Rev. Biochem. 49 (1980) 593. doi: https://doi.org/10.1146/annurev.bi.49.070180.003113

18. Vujisic, L., Krstic, D., Krinulovic, K., Vasic, V., Influence of transition and heavy metal ions on ATP-ases activity in rat synaptic plasma membranes, J. Serb. Chem. Soc. 69 (2004) 541. doi: https://doi.org/10.2298/JSC0407541V

19. Wang, Y., Yu, H., Song, W., An, M., Zhang, J., Luo, H., Shen, Z., Overexpression of synthesized cephalosporin C acylase containing mutations in the substrate transport tunnel, J. Biosci. Bioeng. 113 (2012) 36. doi: https://doi.org/10.1016/j.jbiosc.2011.08.027

20. Kim, D. W., Yoon, K. H., Cloning and high expression of glutaryl 7-aminocephalosporanic acid acylase gene from Pseudomonas diminuta, Biotechnol. Lett. 23 (2001) 1067. doi: https://doi.org/10.1023/A:1010554323405

21. Patett, F., Fischer, L., Spectrophotometric assay for quantitative determination of 7-aminocephalosporanic acid from direct hydrolysis of cephalosporin C, Anal. Biochem. 350 (2006) 304. doi: https://doi.org/10.1016/j.ab.2005.11.043

22. Janssen, M. H., van Langen, L. M., Pereira, S. R., Rantwijk, $F$. V., Sheldon, R. A., Evaluation of the performance of immobilized penicillin $\mathrm{G}$ acylase using active-site titration, Biotechnol. Bioeng. 78 (2002) 425. doi: https://doi.org/10.1002/bit.10208

23. Kallenberg, A. I., van Rantwijk, F., Sheldon, R. A., Immobilization of penicillin $\mathrm{G}$ acylase: the key to optimum performance, Adv. Syn. Cat. 347 (2005) 905. doi: https://doi.org/10.1002/adsc.200505042

24. Tischer, $W$., Kasche, $V$., Immobilized enzymes: crystals or carriers?, Trends Biotechnol. 17 (1999) 326. doi: https://doi.org/10.1016/S0167-7799(99)01322-0

25. Spiess, A. C., Kasche, V., Direct measurement of $\mathrm{pH}$ profiles in immobilized enzyme carriers during kinetically controlled synthesis using CLSM, Biotechnol. Progr. 17 (2001) 294 doi: https://doi.org/10.1021/bp000149e

26. Luo, H., Zhu, L., Chang, Y., Liu, X., Liu, Z., Sun, H., Li, X., $Y u, H$., Shen, Z., Microenvironmental $\mathrm{pH}$ changes in immobilized cephalosporin $\mathrm{C}$ acylase during a proton-producing reaction and regulation by a two-stage catalytic process, Bioresource Technol. 223 (2017)157.

doi: https://doi.org/10.1016/j.biortech.2016.10.038

27. Guisan, J. M., Alvaro, G., Rosell, C. M., Fernandez-Lafuente, $R$., Industrial design of enzymic processes catalysed by very active immobilized derivatives: utilization of diffusional limitations (gradients of $\mathrm{pH}$ ) as a profitable tool in enzyme engineering, Biotechnol. Appl. Biochem. 20 (1994) 357. doi: https://doi.org/10.1111/j.1470-8744.1994.tb00323.x

28. Conti, G., Pollegioni, L., Molla, G., Rosini, E., Strategic manipulation of an industrial biocatalyst--evolution of a cephalosporin C acylase, FEBS J. 281(2014) 2443. doi: https://doi.org/10.1111/febs.12798

29. 29 Søgaard, M., Kadziola, A., Haser, R., Svensson, B., Site-directed mutagenesis of histidine 93, aspartic acid 180, glutamic acid 205, histidine 290, and aspartic acid 291 at the active site and tryptophan 279 at the raw starch binding site in barley alpha-amylase 1, J. Biol. Chem. 268 (1993) 22480 .

30. Chen, Q. X., Zhang, Z., Zhou, X. W., Zhuang, Z. L., Kinetics of inhibition of $\beta$-glucosidase from Ampullarium crossean by bromoacetic acid, Int. J. Biochem. Cell Biol. 32 (2000) 717.

doi: https://doi.org/10.1016/S1357-2725(00)00020-0

31. Boggaram, V., Mannervik, B., An essential histidine residue in the catalytic mechanism of mammalian glutathione reductase, Biochem. Biophys. Res. Commun. 83 (1978) 558. doi: https://doi.org/10.1016/0006-291X(78)91026-4 
32. Golden, E., Paterson, R., Tie, W. J., Anandan, A., Flematti, G., Molla, G., Rosini, E., Pollegioni, L., Vrielink, A., Structure of a class III engineered cephalosporin acylase: comparisons with class I acylase and implications for differences in substrate specificity and catalytic activity, Biochem J. 451 (2013) 217

doi: https://doi.org/10.1042/BJ20121715

33. Mccormick, M. H. (Eli Lilly Com.) Process for the recovery and purification of cephalosporin C. U.S. Pat. Appl. 3,467,654 A, 16 Sep. 1969; C.A. (1970) 2149.

34. Stables, H. C., Briggs, K. (Glexo Group Ltd.) Recovery of cephalosporin $\mathrm{C}$ from fermentation liquor. DE Pat. Appl. 2,852,596, 7 Jun 1979; C.A. (1979) 473138.

35. Ghosh, A. C., Borthakur, S., Roy, M. K., Dutta, N. N., Extraction of cephalosporin $\mathrm{C}$ using supported liquid membrane. Sep. Technol. 5 (1995) 121.

doi: https://doi.org/10.1016/0956-9618(95)00114-L

36. Chae, H. J., In, M. J., Kim, E. Y., Optimization of protease immobilization by covalent binding using glutaraldehyde, Appl. Biochem. Biotechnol. 73 (1998) 195. doi: https://doi.org/10.1007/BF02785655

37. Wehtje, E., Adlercreutz, P., Mattiasson, B., Improved activity retention of enzymes deposited on solid supports, Biotechnol. Bioeng. 41 (1993) 171. doi: https://doi.org/10.1002/bit.260410202
38. Hancock, T. J., Hsu, J. T., Thermal stability studies of a globular protein in aqueous poly (ethylene glycol) by $1 \mathrm{H}$ NMR, Biotechnol. Bioeng. 51 (1996) 410. doi: https://doi.org/10.1002/(SICI)10970290(19960820)51:4<410::AID-BIT4>3.0.CO; 2-L

39. Kazan, D., Ertan, H., Erarslan, A., Stabilization of Escherichia coli penicillin $\mathrm{G}$ acylase against thermal inactivation by cross-linking with dextran dialdehyde polymers, Appl. Microbiol. Biotechnol. 48 (1997) 191. doi: https://doi.org/10.1007/s002530051037

40. Yang, Z., Domach, M., Auger, R., Yang, F. X., Russell, A. J. Polyethylene glycol-induced stabilization of subtilisin, Enzyme Microb. Tech. 18 (1996) 82. doi: https://doi.org/10.1016/0141-0229(95)00073-9

41. Arica, M. Y., Alaeddinoğlu, N. G., Hasirci, V., Immobilization of glucoamylase onto activated pHEMA/EGDMA microspheres: properties and application to a packed-bed reactor, Enzyme Microb. Tech. 22 (1998) 152. doi: https://doi.org/10.1016/S0141-0229(97)00139-7

42. Alvaro, G., Fernandez-Lafuente, R., Blanco, R. M., Guisán, $J$., Stabilizing effect of penicillin G sulfoxide, a competitive inhibitor of penicillin $\mathrm{G}$ acylase: its practical applications, Enzyme Microb. Tech. 13 (1991) 210. doi: https://doi.org/10.1016/0141-0229(91)90130-3 